\title{
Editorial
}

\section{Changing attitudes to brands}

Fifteen years ago, the terms brands and branding were relatively little used, even in marketing circles; now they are on the lips not just of marketing people but also of accountants, analysts, financial journalists and even tax experts.

The reason for this is partly the 'brands on the balance sheet' debate. This burst on the scene in $1987-8$ as a result of Grand Metropolitan's balance sheet valuation of its recently acquired brands (Smirnoff and others acquired as part of Heublein; and Green Giant, Burger King, Häagen-Dazs and others acquired as part of Pillsbury) and Ranks Hovis McDougall's balance sheet valuation of all its brands, acquired and otherwise. However, the continued interest in brands cannot be attributed simply to such innovative balance sheet accounting techniques.

Rather, a fundamental change has taken place over the last fifteen or so years in what constitutes corporate 'worth' and the decision by some companies in the United Kingdom, France, Australasia and elsewhere to include brands on their balance sheets is a reflection of this. In 1980, tangible assets constituted about 80 per cent of the total value of all mergers and acquisitions involving quoted companies in the UK; now that figure is around 30 per cent. In other words, 'goodwill', the somewhat unsatisfactory term used by accountants to describe the difference between a company's tangible assets, as shown on the balance sheet, and the price paid for that company, has risen from 20 per cent to 70 per cent in that short time.

Goodwill is a catch-all term and includes all the intangible assets of a company (brands, patents, copyrights, customer lists, management teams, relationships with suppliers, relationships with customers etc) as well as, in many cases, a premium for control, perhaps even an excessive premium. Thus goodwill covers specific intangible assets such as patents, brands and copyrights where the owner has clear, usually registered, title to those assets and where the assets in question are 'crisp', unequivocal, transferable, mortgageable etc; non-specific generalised intangible assets, where the company has no clear title and where the assets are not transferable or mortgageable; and no underlying assets at all, as is the case with a premium paid for control.

However, in most instances, specific intangible assets (patents, brands and copyrights) constitute most of goodwill and among these the most important type of specific intangible asset is brands, be they product brands, service brands or corporate brands.

The brands on the balance sheet phenomenon is an attempt by companies and their auditors to rectify accountancy anomalies brought about by the growth in the importance of goodwill, and the failure of accounting practice to recognise this. It is not, however, the only manifestation of the growth in importance of goodwill and of brand value. Some companies, for example, are setting up internal licensing systems for their brands - after all, one would not allow a third-party to use one's brands without an adequate royalty income, so why should a company's own subsidiaries be allowed to do so? - and these have significant brand management and tax arbitrage implications. Others are starting to use much more incisive brand monitoring and modelling procedures 
so that brands are subject to much closer, and more accountable, management. Yet others are paying much more attention to brands in the mergers and acquisitions area.

But, in spite of such developments, this phenomenon of increasing 'brand centricity' has not yet gone very far - much less far than it should, given that brands constitute, in most instances, the major elements of corporate worth. We believe, for example, that the tools and the data available to brand managers are often woefully inadequate and little changed from 20 years ago; that brand management frequently occupies too lowly a position in the corporate hierarchy; that important advisers in the branding area, including advertising agencies, are often over self-absorbed and fail to view brands from their client's perspective; and that trade mark attorneys, the legal custodians of brands, frequently perform an overly narrow and legalistic role and fail to view or protect brands in an appropriately commercial fashion.

We see the 'brands revolution', therefore, as still having a long, long way to go, though the changes which have taken place in the brands arena in less than 15 years are, nonetheless, remarkable.

John Murphy Editorial Board 